Gut, 1963, 4, 145

\title{
Primary lymphoid neoplasms of the stomach
}

\author{
H. A. ELLIS AND R. LANNIGAN \\ From the Department of Pathology, University of Birmingham
}

EDITORIAL SYNOPSIS Primary lymphoid neoplasms of the stomach may closely simulate carcinomata but carry an appreciably better prognosis after surgical treatment. This paper reports a clinical and pathological study of local gastric lymphoid tumours and also studies in patients with gastric involvement with generalized reticulosis.

Although the malignant reticuloses are generally widely distributed throughout the body and are probably multifocal in origin, similar neoplasms apparently originating at one site have been described in various organs, e.g., the intestine (Ullman and Abeshouse, 1932; Marcuse and Stout, 1950; Irvine and Johnstone, 1955), lung (Rose, 1957; Sternberg, Sidransky, and Ochsner, 1959), thyroid (Kellett and Sutherland, 1949; Brewer and Orr, 1953; Walt, Woolner, and Black, 1957), and bones (Jaffe, 1958). Primary lymphoid neoplasms of stomach are comparatively rare and though they have been extensively reported in the American literature (Taylor, 1939; Snoddy, 1952; Allen, Donaldson, Sniffen, and Goodall, 1954; Thorbjarnarson, Beal, and Pearce, 1956) only a few small series (Skrimshire, 1955; Azzopardi and Menzies, 1960) or individual cases have been described in Britain.

From results reported in the literature some of these gastric neoplasms seem to have a better prognosis than carcinoma, although their behaviour is apparently unpredictable from histological examination. The following investigations were carried out in order to compare the histological, clinical, and follow-up findings in a series of cases collected in the United Birmingham Hospitals and the Regional Histological Collection of the Department of Pathology, University of Birmingham.

\section{MATERIALS AND METHODS}

All cases described as reticulosarcoma, lymphosarcoma, reticulosis of any type, sarcoma, or anaplastic carcinoma of stomach in the surgical histology files of the United Birmingham Hospitals from 1950 to 1960 and in the Regional Histological Collection from 1953 to 1960 were examined histologically. Initial studies were made independently and without reference to other data. Stained sections and paraffin blocks were available and all undifferentiated tumours were stained with Ehrlich's haematoxylin and eosin, and by Gomori's method for reticulin, by the periodic acid-Schiff technique, and Southgate's mucicarmine. Alcian blue and Van Gieson stains were also occasionally employed. Altogether 240 tumours of stomach were examined.

For purposes of comparison with this surgical series, all cases of malignant reticulosis, excluding leukaemia, extracted from the post-mortem records of the Queen Elizabeth Hospital, Birmingham, from 1950 to 1959 were examined. In addition two instances of primary gastric lymphoid neoplasm which had been encountered at necropsy were found in the Regional Histological Collection.

\section{DIAGNOSTIC CRITERIA}

A definitive diagnosis of lymphoid neoplasm is as difficult in the stomach as elsewhere (cf. thyroid, Brewer and Orr, 1953), as differentiation from anaplastic carcinoma can never be absolute. Using the criteria described by the various authors mentioned above and from observations on the material itself, it was possible to select a group of neoplasms which differed from anaplastic carcinoma in general pattern and cytology. This was not a homogeneous group and it could be subdivided into two main types, lymphosarcoma and reticulosarcoma. The lymphosarcomata consisted of closely packed groups of cells with little recognizable cytoplasm and dense nuclei, identical in appearance to small lymphocytes (Figs. 1 and 2). In some of these tumours the cell pattern was uniform, but in others larger cells with more cytoplasm and larger open nuclei were also found. In two cases there was a recognizable follicular pattern but this was focal and was not a major feature (Fig. 3). The type designated reticulosarcoma had larger cells with more cytoplasm and rounded or slightly twisted nuclei with prominent nucleoli (Fig. 4). Occasionally multinucleated cells were seen and in some tumours 


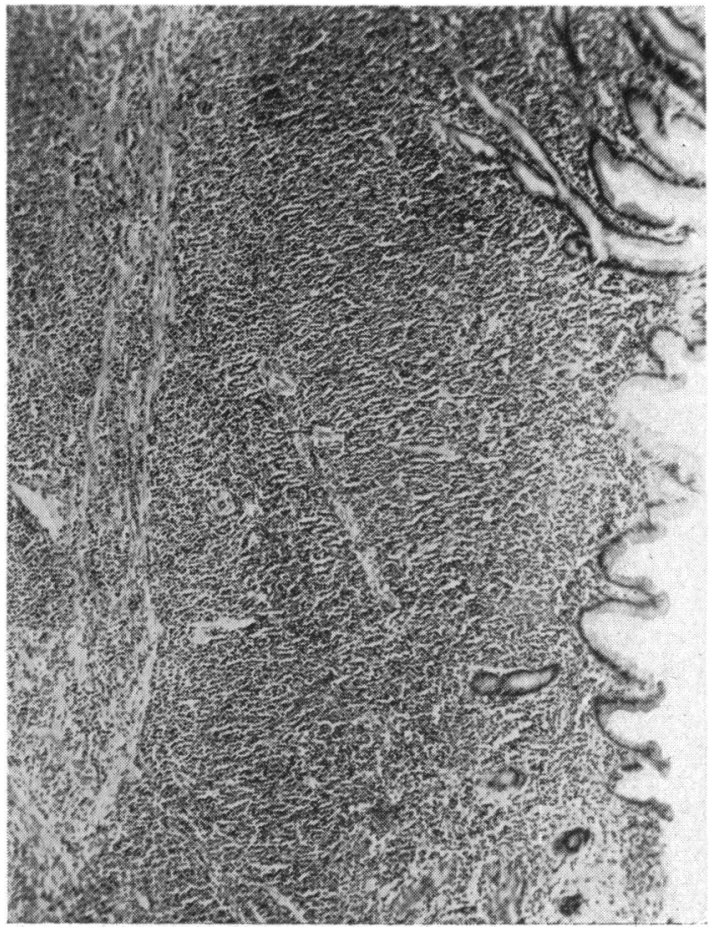

FIG. 1

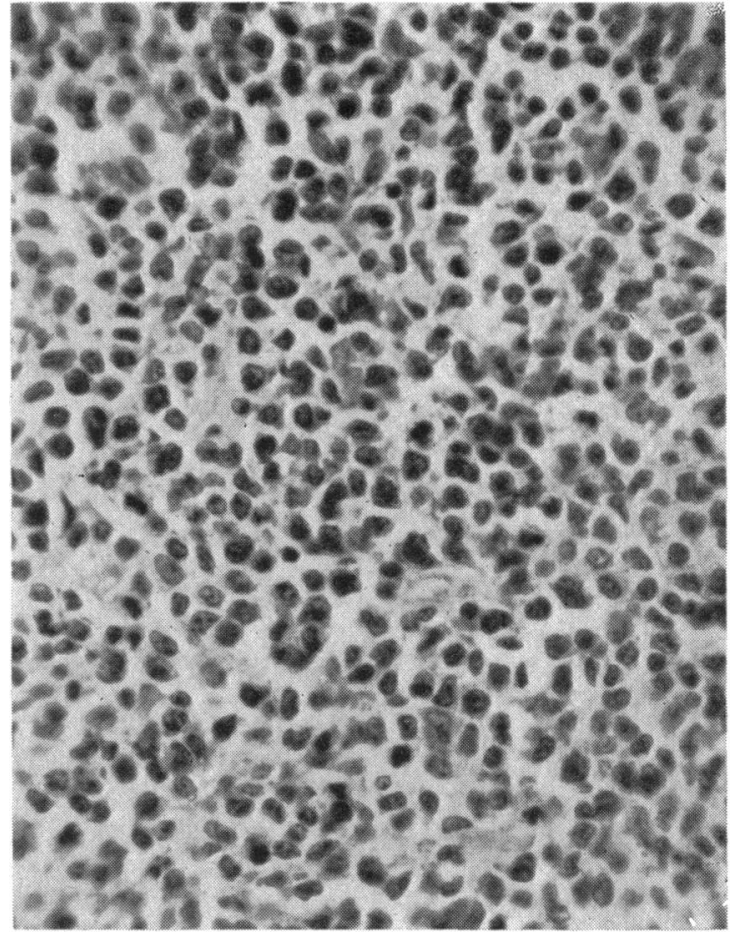

FIG. 2

FIg. 1. Lymphosarcoma involving the mucosa and submucosa. The muscularis mucosae is preserved. Haematoxylin and eosin $\times 75$.

FIG. 2. High-power view of lymphosarcoma. Haematoxylin and eosin $\times 450$.

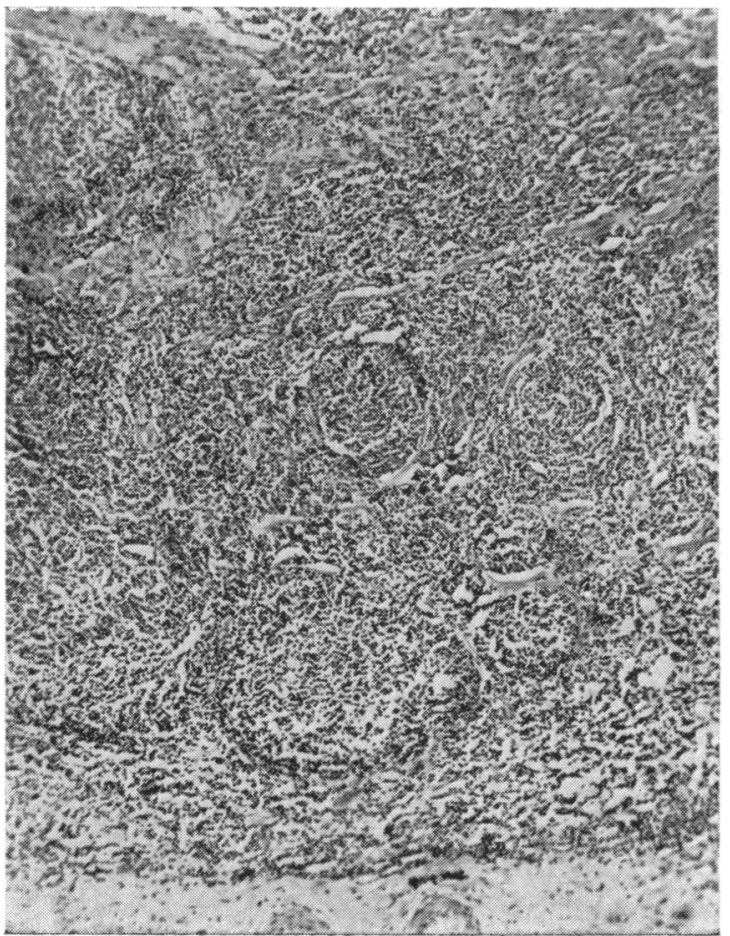

FIG. 3. Area of lymphosarcoma showing a follicular pattern. Haematoxylin and eosin $\times 75$.

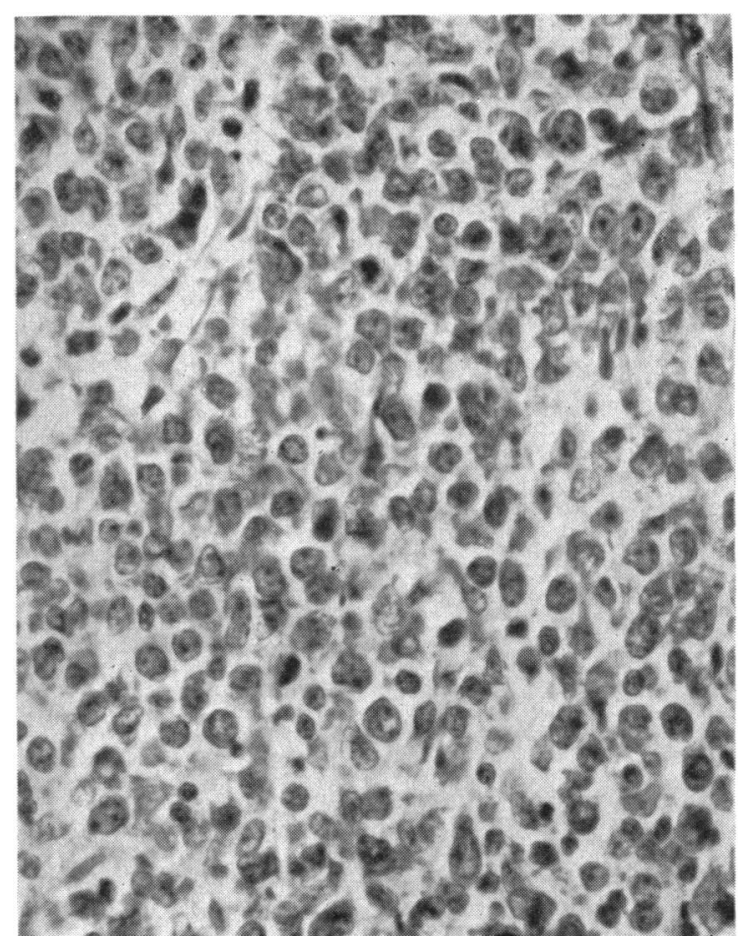

FIG. 4. High-power view of reticulosarcoma. Haematoxylin and eosin $\times 450$.

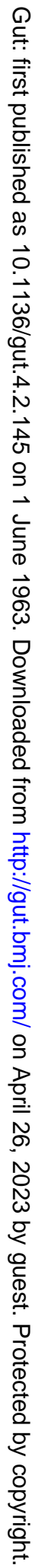




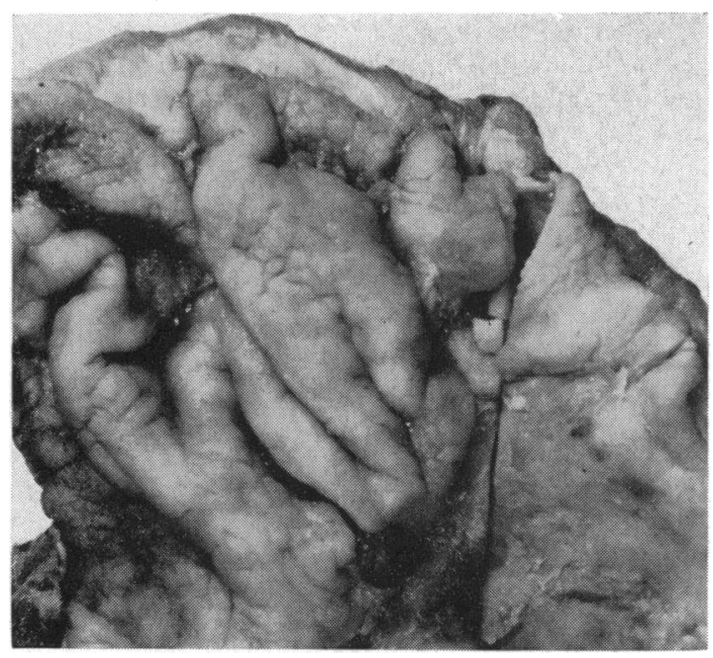

FIG. 5. Margin of ulcerated reticulosarcoma showing giant rugae. Fixed specimen $\times 1 \cdot 5$.

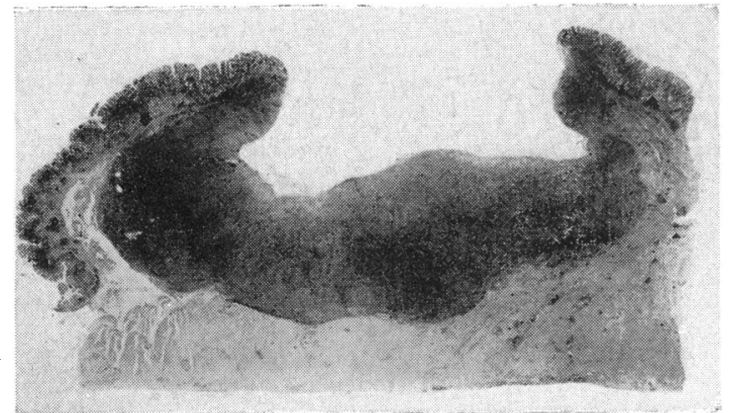

FIG. 6. Section of ulcerated lymphosarcoma with raised edges. To the left the tumour is invading the muscularis as a solid mass and to the right is infiltrating between muscle fibres. Van Giesen $\times 3 \cdot 5$.

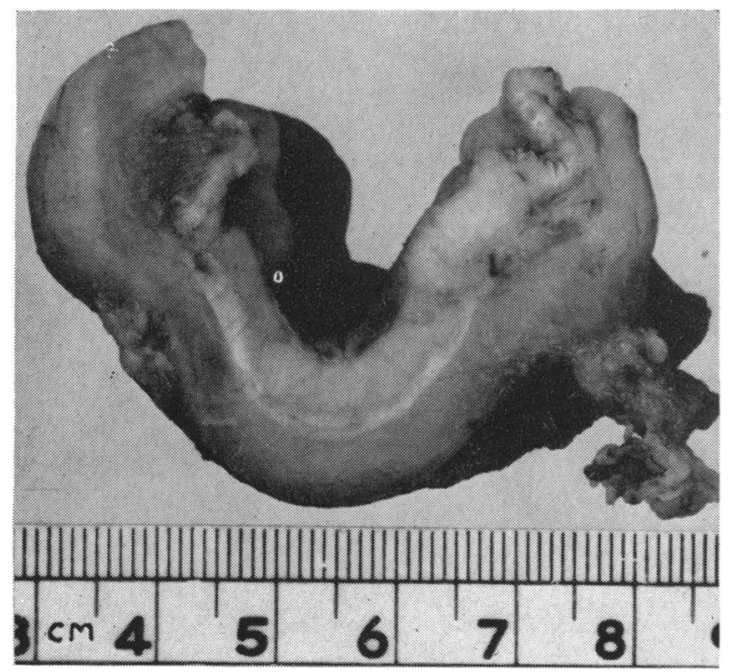

FIG. 7. Section of superficial diffusely infiltrating reticulosarcoma with ulceration in the centre. the cell pattern was more pleomorphic. Eosinophils and plasma cells were sometimes seen in both groups. Stains for mucin were negative in all cases.

\section{RESULTS}

SURGICAL SERIES Twenty-four cases were diagnosed as lymphoid neoplasms, nine lymphosarcoma and 15 reticulosarcoma. Hodgkin's disease and giant follicular lymphoma were not encountered but a follicular pattern was noted in some areas in two cases.

The relevant clinical, pathological, and follow-up data are shown in Table I. There were 16 males and eight females. The age range was 29-71 years, with the peak incidence in the seventh decade (nine cases) and this did not differ to any great extent from carcinoma of stomach.

Macroscopic appearances Macroscopic descriptions were available in 20 of the 24 cases. None had been diagnosed as lymphoid neoplasm on naked-eye examination alone and the tumours presented in four main types: 1 Lesions indistinguishable from chronic peptic ulcers; 2 polypoid tumours, either single or multiple; 3 large single or multiple ulcers with raised rolled edges (Figs. 5 and 6); 4 diffusely infiltrating tumours, sometimes associated with giant rugae (Figs. 5 and 7).

Appearances corresponding to each of these types have also been seen in carcinoma of the stomach. In many cases the tumours were superficial, but in others the muscle was penetrated deeply. In two cases perforation was the initial indication for surgery. The lower end of the oesophagus was invaded in two cases.

Histological appearances Apart from the cytological appearances initially used in selection and the absence of mucin staining, there were several histological features of interest. The lamina propria and submucosa were usually very heavily involved and in some cases the muscle coat was not deeply penetrated. The muscularis mucosae was often preserved even when the neoplastic process continued from the lamina propria to the submucosa (Fig. 1). Fibrosis in relation to the neoplasm was uncommon but in a few cases there was fairly dense fibrosis in relation to ulcerated areas. The tumours invaded the muscle coat either on a broad front or by infiltration between individual muscle fibres (Fig. 6) but on occasions infiltration was mainly along the fibrous septae (Fig. 8). This mode of spread, in our opinion, did not differ substantially from that of carcinoma.

Giant rugae associated with some of these cases did not always show infiltration by neoplastic cells. In some the appearances were due to oedema and 
TABLE I

DETAILS OF 24 CASES OF PRIMARY GASTRIC LYMPHOID NEOPLASMS

\begin{tabular}{|c|c|c|c|c|c|c|c|c|}
\hline $\begin{array}{l}\text { Case } \\
\text { No. }\end{array}$ & Sex & Age & Main Clinical Features & Treatment & $\begin{array}{l}\text { Macroscopic } \\
\text { Appearances }\end{array}$ & Histology & $\begin{array}{l}\text { Lymph } \\
\text { Node } \\
\text { Involve- } \\
\text { ment }\end{array}$ & Course \\
\hline
\end{tabular}

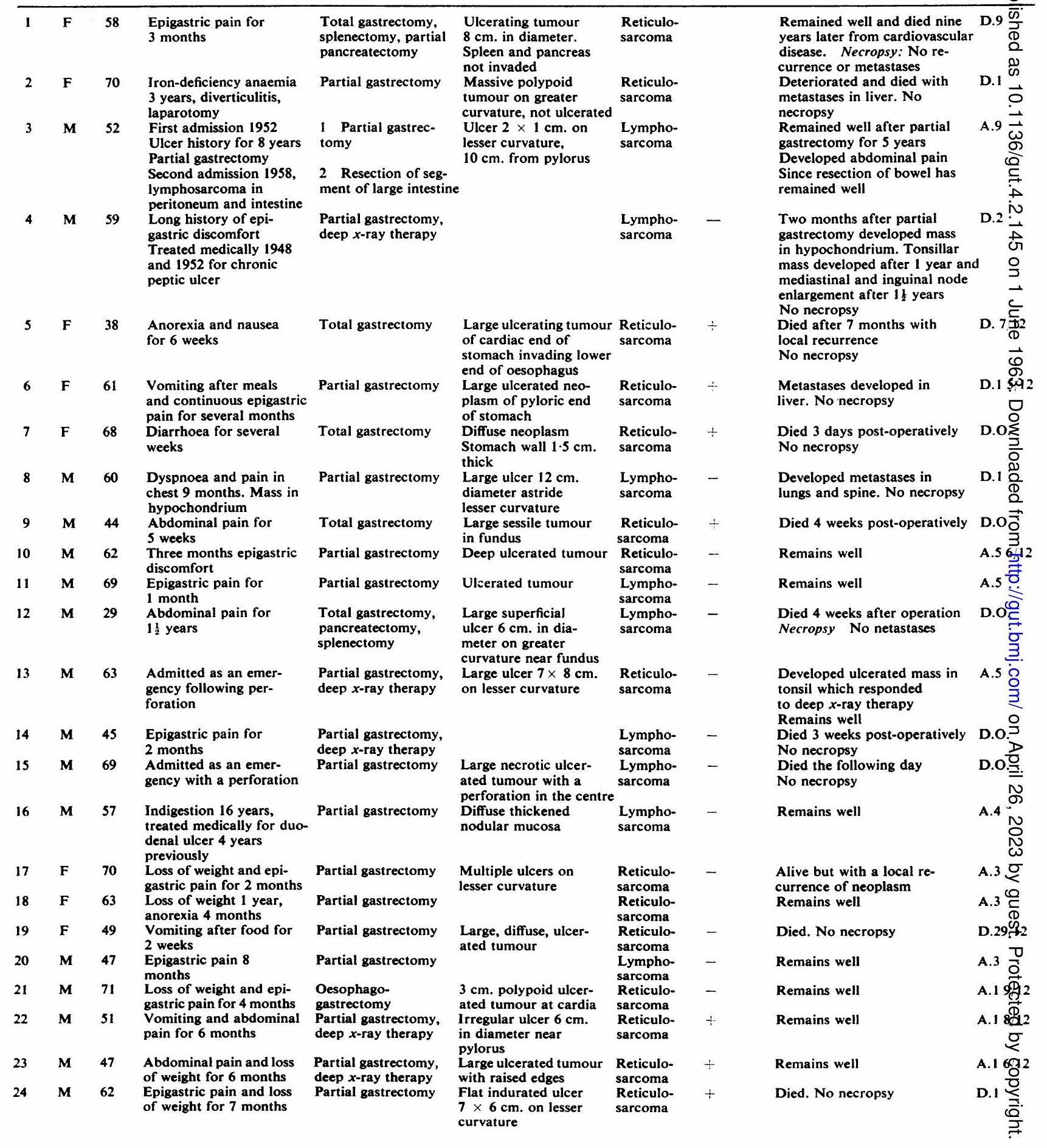




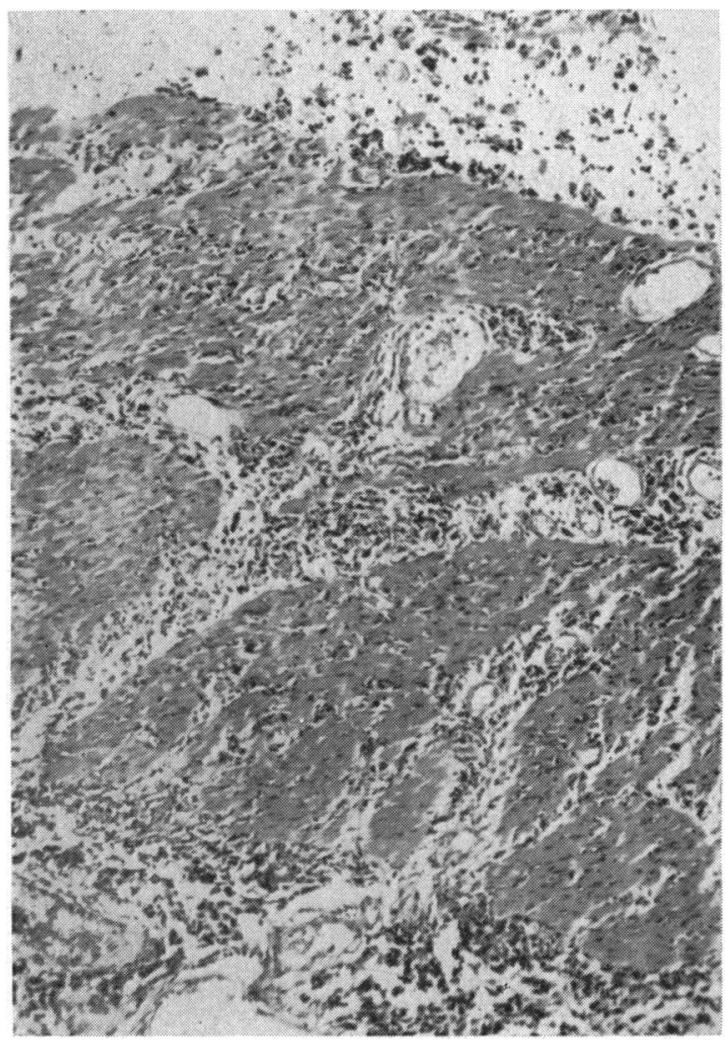

FIG. 8. Reticulosarcoma infiltrating along fibrous septae and between muscle fibres. Haematoxylin and eosin $\times 100$.

similar appearances were sometimes found in the submucosa in the absence of giant rugae. The reticulin pattern was very variable, not only from case to case but also in different parts of the same specimen. In general the pattern in carcinoma was much heavier but this was often associated with fibrosis.

Lymph node involvement of 20 cases in which sections of lymph nodes were available, seven showed involvement. Usually the whole lymph node was replaced but in a few cases localized deposits were found.

Follow-up data Five patients died in the immediate post-operative period, leaving 19 in whom follow-up studies could be carried out for a minimum period of 18 months. A post-mortem examination was carried out on one of the five patients dying after operation and no involvement of other organs was found (case 12).

The survival rates are shown in Table II, in which a comparison is made with all histologically proven cases of carcinoma of stomach subjected to partial or total gastrectomy and with a group of poorly differentiated gastric carcinomata.
TABLE II

SURVIVAL RATES FOR GASTRIC LYMPHOID NEOPLASMS AND CARCINOMA OF STOMACH

\begin{tabular}{rlllll} 
Total $^{1}$ & \multicolumn{5}{l}{ \% Survival (years) } \\
\cline { 2 - 6 } & 1 & 2 & 3 & 4 & 5 \\
\hline 19 & 95 & 73 & 64 & 55 & 50 \\
419 & 64 & 40 & 30 & 23 & 20 \\
72 & 60 & 36 & 26 & 17 & 11
\end{tabular}

$\begin{array}{lrrrrrr}\text { Gastric lymphoid neoplasms } & 19 & 95 & 73 & 64 & 55 & 50 \\ \text { Gastric carcinoma all types }^{2} & 419 & 64 & 40 & 30 & 23 & 20 \\ \text { Gastric carcinoma poorly } & 72 & 60 & 36 & 26 & 17 & 11\end{array}$

differentiated $^{2}$

'Excluding post-operative deaths.

${ }^{2}$ Regional Histological Collection 1951-55. All cases treated by surgical resection and examined histologically.

In the first year survivals there is a highly significant difference $(P<0.001)$ between the lymphoid group of tumours and the anaplastic carcinoma group but thereafter the numbers become too small to give significance to individual years of survival. There is, however, a clear trend where the proportionate survival rate increases in favour of the lymphoid group. This lends support to the view that gastric lymphoid neoplasms form a group distinct from anaplastic carcinoma.

POST-MORTEM SERIES The results are shown in Table III. Of a total of 54 cases of systematized reticulosis (including four cases in which the main lesions were in the gastrointestinal tract), gastric involvement was found in 11 cases $(30 \%$ of reticulosarcoma and $31 \%$ of lymphosarcoma cases). In one of these 11 cases the major post-mortem finding was the presence of multiple lesions in the gastrointestinal tract. The relevant pathological and clinical findings of these 11 cases are included in Table IV.

\section{TABLE III}

NECROPSY SERIES QUEEN ELIZABETH HOSPITAL, 1950-1959, FOR ALL CASES OF RETICULOSIS EXCLUDING LEUKAEMIA

\begin{tabular}{lrccc} 
& Total & $\begin{array}{c}\text { Reticulo- } \\
\text { sarcoma }\end{array}$ & $\begin{array}{l}\text { Lympho- } \\
\text { sarcoma }\end{array}$ & $\begin{array}{c}\text { Hodgkin's } \\
\text { Disease }\end{array}$ \\
\hline $\begin{array}{l}\text { All cases } \\
\text { Generalized }\end{array}$ & 54 & 23 & 13 & 18 \\
Gastrointestinal & 50 & 20 & 13 & 17 \\
$\begin{array}{l}\text { Gastric lesions } \\
\text { Generalized cases }\end{array}$ & 11 & 3 & 0 & 1 \\
$\begin{array}{l}\text { Gastrointestinal } \\
\text { cases }\end{array}$ & 10 & 6 & 4 & 0 \\
& 1 & 1 & 4 & 0 \\
\end{tabular}

The gross appearances of these lesions did not differ substantially from those of the surgical series, except that multiple deposits were much more common and the tumours were mainly superficially situated within the gastric mucosa. The cytological appearances of the lesions in the surgical and post-mortem series were indistinguishable. 
TABLE IV

DETAILS OF 11 CASES OF WIDESPREAD RETICULOSIS WITH GASTRIC INVOLVEMENT AT NECROPSY

\begin{tabular}{|c|c|c|c|c|c|c|}
\hline $\begin{array}{l}\text { Case } \\
\text { No. }\end{array}$ & Sex & Age & Main Clinical Features & Main Necropsy Findings & Nature of Gastric Involvement & Diagnosis \\
\hline 25 & $\mathbf{M}$ & 53 & $\begin{array}{l}\text { Six months' loss in weight, } \\
\text { lymphadenopathy, hepato- } \\
\text { megaly }\end{array}$ & $\begin{array}{l}\text { Generalized lymphadeno- } \\
\text { pathy, tumour in stomach, } \\
\text { small intestine, spleen, heart, } \\
\text { kidney, adrenal, and thyroid }\end{array}$ & $\begin{array}{l}\text { Three mucosal nodules, one } \\
\text { showing erosion }\end{array}$ & Reticulosarcoma \\
\hline 26 & $\mathbf{F}$ & 78 & $\begin{array}{l}\text { Eight months' swelling } \\
\text { angle of jaw and neck due } \\
\text { to large lymph nodes, } \\
\text { tumour mass in nasopharynx }\end{array}$ & $\begin{array}{l}\text { Tumour in stomach, naso- } \\
\text { pharynx, lung, liver and } \\
\text { kidneys, cervical lymph- } \\
\text { adenopathy }\end{array}$ & $\begin{array}{l}\text { One mucosal lesion upper part } \\
\text { lesser curve, raised margin ulcer- } \\
\text { ated base measuring } 6 \times 4 \mathrm{~cm} \text {. }\end{array}$ & Reticulosarcoma \\
\hline 27 & $\mathbf{M}$ & 59 & $\begin{array}{l}\text { Four years' loss in weight, } \\
\text { steatorrhoea, macrocytic } \\
\text { anaemia }\end{array}$ & $\begin{array}{l}\text { Tumour in stomach jejunum } \\
\text { and ileum, mesenteric nodes } \\
\text { involved }\end{array}$ & $\begin{array}{l}\text { One mucosal lesion in fundus } \\
\text { measuring } 2 \times 1 \mathrm{~cm} \text {., raised } \\
\text { edges ulcerated base }\end{array}$ & Reticulosarcoma \\
\hline 28 & $\mathbf{F}$ & 53 & $\begin{array}{l}\text { Four months' swelling axil- } \\
\text { lary lymph nodes, abdominal } \\
\text { mass palpable }\end{array}$ & $\begin{array}{l}\text { Generalized lymph node in- } \\
\text { volvement, tumour in stomach, } \\
\text { spleen, kidney, lung, liver, } \\
\text { and heart }\end{array}$ & $\begin{array}{l}\text { Several subserous nodules } \\
\text { measuring } 0.3 \mathrm{~cm} \text {. diameter }\end{array}$ & Reticulosarcoma \\
\hline 29 & $\mathbf{M}$ & 78 & $\begin{array}{l}\text { Seven months' swelling } \\
\text { axillary lymph nodes with } \\
\text { increasing weakness, hepato- } \\
\text { megaly }\end{array}$ & $\begin{array}{l}\text { Generalized lymph node } \\
\text { involvement, tumour in } \\
\text { tonsil, stomach, oesophagus, } \\
\text { and spleen }\end{array}$ & $\begin{array}{l}\text { Multiple discrete musocal } \\
\text { nodules along lesser curve, } \\
\text { some ulcerated }\end{array}$ & Lymphosarcoma \\
\hline 30 & $\mathbf{F}$ & 69 & $\begin{array}{l}\text { Six months' general lymph } \\
\text { node enlargement and abdo- } \\
\text { minal pain, hepatospleno- } \\
\text { megaly }\end{array}$ & $\begin{array}{l}\text { Generalized lymph node } \\
\text { involvement }\end{array}$ & Single small mucosal deposit & Reticulosarcoma \\
\hline 31 & $\mathbf{M}$ & 67 & $\begin{array}{l}\text { Eighteen months' cervical } \\
\text { and mediastinal lymphadeno- } \\
\text { pathy with dyspnoea and } \\
\text { dysphagia }\end{array}$ & $\begin{array}{l}\text { Enlarged paratracheal cer- } \\
\text { vical and mediastinal lymph } \\
\text { nodes }\end{array}$ & $\begin{array}{l}\text { Multiple mucosal nodules } \\
\text { measuring up to } 5 \mathrm{~cm} \text {. in dia- } \\
\text { meter }\end{array}$ & Lymphosarcoma \\
\hline 32 & $\mathbf{M}$ & 61 & $\begin{array}{l}\text { Twenty-seven years' attacks } \\
\text { of diarrhoea. Five years } \\
\text { previously found to have } \\
\text { steatorrhoea. Four months' } \\
\text { generalized lymph node } \\
\text { enlargement }\end{array}$ & $\begin{array}{l}\text { Generalized enlargement of } \\
\text { lymph nodes, tumour in } \\
\text { stomach, small intestine, lung, } \\
\text { kidney, pancreas, adrenal, } \\
\text { and liver }\end{array}$ & $\begin{array}{l}\text { Multiple mucosal nodules } \\
\text { majority ulcerated measuring up } \\
\text { to } 5 \mathrm{~cm} \text {. diameter, mainly in } \\
\text { fundus and body }\end{array}$ & Reticulosarcoma \\
\hline 33 & $\mathbf{F}$ & 30 & $\begin{array}{l}\text { Two weeks' pyrexia with } \\
\text { cough and dyspnoea. Chest } \\
\text { radiograph revealed 'mottled' } \\
\text { pattern of all lobes }\end{array}$ & $\begin{array}{l}\text { Tumour deposits in stomach, } \\
\text { oesophagus, pleura, lungs, } \\
\text { pericardium, liver, kidney } \\
\text { and thyroid. Generalized } \\
\text { lymph node involvement }\end{array}$ & $\begin{array}{l}\text { Two ulcerated mucosal nodules } \\
\text { one } 2.5 \mathrm{~cm} \text {. diameter in mid } \\
\text { lesser curve, the other } 1.0 \mathrm{~cm} \text {. } \\
\text { diameter on anterior wall }\end{array}$ & Reticulosarcoma \\
\hline 34 & $\mathbf{M}$ & 54 & $\begin{array}{l}\text { Three months' cervical and } \\
\text { mediastinal lymph node } \\
\text { enlargement with superior } \\
\text { vena caval obstruction and } \\
\text { pleural effusion }\end{array}$ & $\begin{array}{l}\text { Large mediastinal mass of } \\
\text { tumour, lesions in stomach, } \\
\text { kidney, and thyroid }\end{array}$ & $\begin{array}{l}\text { Five ulcerated mucosal nodules } \\
\text { measuring up to } 1.5 \mathrm{~cm} \text {. dia- } \\
\text { meter on mid-posterior wall }\end{array}$ & Lymphosarcoma \\
\hline 35 & $\mathbf{M}$ & 49 & $\begin{array}{l}\text { Eight months' generalized } \\
\text { lymph node enlargement } \\
\text { and pleural effusion }\end{array}$ & $\begin{array}{l}\text { Tumour in lymph nodes } \\
\text { stomach, spleen, liver, and } \\
\text { pancreas }\end{array}$ & $\begin{array}{l}\text { Multiple raised ulcerated } \\
\text { nodules in mucosa up to } 2 \mathrm{~cm} \text {. } \\
\text { diameter on posterior wall }\end{array}$ & Lymphosarcoma \\
\hline
\end{tabular}

TABLE V

DETAILS OF TWO CASES OF LOCALIZED GASTRIC LYMPHOID NEOPLASMS FROM THE REGIONAL HISTOLOGICAL COLLECTION

\begin{tabular}{cllll} 
Case No. & Sex & Age & Main Clinical Features & Main Necropsy Findings \\
\hline 36 & M & 54 & $\begin{array}{l}\text { Nausea and pain in epigastrium for } \\
\text { nine months. Died with haematemesis }\end{array}$ & $\begin{array}{l}\text { Diffusely infiltrating tumour of stomach } \\
\text { invading spleen, tail of pancreas, and kidney }\end{array}$
\end{tabular}

$\begin{array}{llll}37 & \text { M } & 37 & \text { Six weeks' diarrhoea and loss of weight }\end{array}$

Large solitary ulcer of stomach penetrat- Reticulosarcoma ing pancreas, peritonitis

The two cases of primary lymphoid neoplasms of stomach coming to necropsy are shown in Table V. Widespread metastases were not found and the tumours were confined to the stomach area.

\section{DISCUSSION}

The results of this investigation confirm those of other series, namely, that the survival rate is higher in this group of tumours than in carcinoma of the stomach. The five-year survival is similar to that in other series; for example, Allen et al. (1954) had $50 \%$ survival rate at five years. No difference has been found between the histological appearances of the tumours in those patients who survive for long periods and those who die soon after a diagnosis has been made. Similarly no cytological differences have been noted in the deposits in the 
stomach in systemic reticuloses and those where the lesions appear to be primary, although in the former the lesions tend to be more superficial in position and there is comparatively little deep invasion. In addition, the histological appearances were no guide to the prognosis: thus of the two patients surviving longest, case 1 (nine years) had a reticulosarcoma and case 3 (nine years) a lymphosarcoma.

PATHological FEATURes The gross features of these neoplasms were not very helpful in the diagnosis, as similar appearances could be found in carcinoma. This has also been noted in gastroscopic (Palmer, 1950) and radiological examinations (Redd, 1959) where differentiation is not possible in most cases.

On a histological basis the lymphosarcoma is very readily recognized and confusion with carcinoma is unlikely to occur. However, the reticulosarcomata more closely resemble anaplastic carcinoma and it may be quite impossible on occasion to differentiate the two groups. Various histological rather than cytological criteria have been described by different authors. The most important differentiation lies in the completely structureless nature of the reticulosarcomata and the absence of mucus secretion. Other differences are the absence of any transitions between the epithelium and the tumour, the superficial nature of some of these tumours, with heavy involvement of the mucosa and submucosa and frequent preservation of the muscularis mucosae (Fig. 1), and the frequent absence of fibrosis except in relation to some ulcerated zones and the method of invasion. The method of invasion was not found to be helpful in individual cases and the reticulin pattern was too variable to be of any assistance.

When all these factors are considered, one is still left with the problem that the basic histological method of differentiating reticulosarcoma is by excluding recognizable carcinoma and other forms of sarcoma. This is an unsatisfactory position, but the same conditions are found in other sites. Willis (1948) has emphasized the difficulties inherent in classification of undifferentiated tumours. With the small cell lymphosarcomata the position is quite different, as these tumours are cytologically readily distinguishable from carcinoma. Even in this group, however, their subsequent behaviour is unpredictable.

RELATION OF PRIMARY LYMPHOID NEOPLASMS TO GENERALIZED RETICULOSES None of the surgical cases was considered to have a generalized reticulosis at the time of operation and conversely none of the generalized reticuloses presented clinically as a primary gastric neoplasm. However, the subsequent behaviour of apparently primary tumours suggests that in some cases at least a generalized form develops. Thus cases 4 and 13 subsequently developed lesions in the tonsils. Cruickshank (1957) has reported three cases with involvement of the tonsils and gastrointestinal system, in which the lesions were apparently localized to these areas. However, in our series case 4 later developed a generalized lymphadenopathy, so that the association of tumour in these two sites would appear to be coincidental.

Apart from five post-operative deaths, eight other patients have died between seven months and nine years after operation. A post-mortem examination was carried out in only one of these patients (case 1) nine years after the removal of the neoplasm, and no evidence of metastases was found. The other seven patients died with clinical evidence of metastases or local recurrence in the abdomen. Of the 11 patients still alive, case 3 had a recurrence in the abdomen after six years but is still alive nine years after operation, case 17 has a local recurrence, and all others have no evidence of recurrence. It appears that in some cases the neoplastic process becomes generalized, but in others the lesion seems to remain localized to the stomach.

The assumption has been made that these are truly neoplastic lesions but the considerations of Brewer and Orr (1953) in the thyroid apply equally to the stomach. The behaviour of some of these lesions, which on a histological basis would be considered highly malignant, makes it very difficult to exclude the possibility that some may be reactive rather than neoplastic. This, however, remains a speculation and at the moment there is no means of deciding which lesions will metastasize and which will apparently be cured.

We wish to acknowledge the help and cooperation of Dr. S. C. Dyke, Curator of the Regional Histological Collection, and the pathologists on the Birmingham Regional Hospital Board. We also wish to thank Dr. J. A. H. Waterhouse and Miss D. J. Powell, of the Department of Medical Statistics, University of Birmingham, and Miss J. M. Levi, of the Follow-up Department.

\section{REFERENCES}

\footnotetext{
Allen, A. W., Donaldson, G., Sniffen, R. C., and Goodall, F., Jr. (1954). Primary malignant lymphoma of the gastro-intestinal tract. Ann. Surg., 140, 428-438.

Azzopardi, J. G., and Menzies, T. (1960). Primary malignant lymphoma of the alimentary tract. Brit. J. Surg., 47, 358-366.
} 
Brewer, D. B., and Orr, J. W. (1953). Struma reticulosa: a reconsideration of the undifferentiated tumours of the thyroid J. Path. Bact., 65, 193-208.

Cruickshank, A. H. (1957). Tonsillar involvement in sarcoma of the alimentary lymphoid tissue. Brit. J. Cancer, 11, 170-174.

Irvine, W. T., and Johnstone, J. M. (1955). Lymphosarcoma of the small intestine with special reference to perforating tumours. Brit. J. Surg., 42, 611-618.

Jaffe, H. L. (1958). Tumours and Tumorous Conditions of the Bones and Joints, p. 415. Kimpton, London.

Kellett, H. S., and Sutherland, T. W. (1949). Reticulosarcoma of the thyroid gland. J. Path. Bact., 61, 233-244.

Marcuse, P. M., and Stout, A. P. (1950). Primary lymphosarcoma of the small intestine. Analysis of 13 cases and review of the literature. Cancer, 3, 459-474.

Palmer, E. D. (1950). The sarcomas of the stomach: a review with reference to gross pathology and gastroscopic manifestations. Amer. J. dig. Dis., 17, 186-195.

Redd, B. L., Jr. (1959). Lymphosarcoma of the stomach. Review and case reports. Amer. J. Roentgenol., 82, 634-650.
Rose, A. H. (1957). Primary lymphosarcoma of the lung. J. thorac. Surg., 33, 254-263.

Skrimshire, J. F. P. (1955). Lymphoma of the stomach and intestine. Quart. J. Med., 24, 203-214.

Snoddy, W. T. (1952). Primary lymphosarcoma of the stomach. Gastroenterolog.v, 20, 537-553.

Sternberg, W. H., Sidransky, H., and Ochsner, S. (1959). Primary malignant lymphomas of the lung. Cancer, 12, 806-819.

Taylor, E. S. (1939). Primary lymphosarcoma of the stomach. Ann. Surg., 110, 200-221.

Thorbjarnarson, B., Beal, J. M., and Pearce, J. M. (1956). Primary malignant lymphoid tumours of the stomach. Cancer, 9 712-717.

Ullman, A., and Abeshouse, B. S. (1932). Lymphosarcoma of the small and large intestines. Ann, Surg., 95, 878-915.

Walt, A. J., Woolner, L. B., and Black, B. M. (1957). Primary malignant lymphoma of the thyroid. Cancer, 10, 663-677.

Willis, R. A. (1948). Pathology of Tumours, p. 129. Butterworth, London. 